Jurnal Interpretasi Hukum | ISSN: 2746-5047

Vol. 2, No. 3-Desember 2021, Hal. 678-682| Tersedia online di

https://www.ejournal.warmadewa.ac.id/index.php/juinhum

DOI: https://doi.org/10.22225/juinhum.2.3.4196.678-682

\title{
PERTANGGUNGJAWABAN PIDANA KORPORASI TERHADAP PENCEMARAN LINGKUNGAN HIDUP DITINJAU DARI UNDANG-UNDANG CIPTA KERJA
}

\author{
Kadek Dicky Candra Mahendra, I Nyoman Gede Sugiartha, Luh Putu Suryani \\ Faultas Hukum Universitas Warmadewa, Denpasar-Bali, Indonesia \\ dickycandra1112@gmail.com, nyomansugiartha14@gmail.com, putusuryani099@gmail.com
}

\begin{abstract}
Abstrak
Kegiatan manusia yang kurang terkontrol, menjadikan lingkungan hidup yang bersih dan sehat semakin berkurang, hal tersebut disebabkan oleh bumi saat ini semakin tua dan aktivitas dari manusia itu sendiri yang tidak melestarikan dengan baik lingkungan. Manusia memiliki peran dan tanggung jawab untuk memberdayakan lingkungan untuk menjaga ekosistem. Namun kenyataan saat ini, sebagian besar tindak pidana lingkungan hidup seringkali melibatkan korporasi. Penelitian ini bertujuan untuk mengkaji pengaturan tindak pidana oleh korporasi dalam perspektif Undang-undang cipta kerja dan mengungkapkan sanksi pidana terhadap korporasi yang melakukan tindak pencemaran lingkungan ditinjau dari Undang-undang cipta kerja. Penelitian ini menggunakan tipe penelitian normatif, dengan pendekatan Perundang-undangan. Adapun yang dijadikan sebagai data primer yaitu UU Nomor 32 Tahun 2009, UU Nomor 11 Tahun 2020 tentang Cipta Kerja menjadi dasar hukum untuk mengetahui pengaturan pidana dan sanksi pidana terhadap pertanggungjawaban pidana korporasi terhadap pencemaran lingkungan hidup ditinjau dari undang-undang cipta kerja. Data dikumpulkan menggunakan teknik studi kepustakaan. Setelah data peneltian terkumpul diolah secara elaborasi yakni menggabungkan sumber bahan hukum primer, sekunder dan tersier tadi dengan logika deduktif dan induktif. Hasil penelitian ini menunjukkan bahwa tindak pidana korporasi pada hakikatnya merupakan tindakan fungsional dan dalam bentuk delik penyertaan. Sanksi pidana penjara adalah dijatuhi 1/3 kepada pengurus korporasi.
\end{abstract}

Kata Kunci: Korporasi, Lingkungan, Pertanggungjawaban

\begin{abstract}
Human activities that are less controlled, make a clean and healthy living environment less and less, this is because the earth is currently getting older and the activities of humans themselves are not properly preserving the environment. Humans have a role and responsibility to empower the environment to maintain the ecosystem. However, the current reality is that most environmental crimes often involve corporations. This study aims to examine the regulation of criminal acts by corporations in the perspective of the Copyright Act and to reveal criminal sanctions against corporations that commit acts of environmental pollution in terms of the Copyright Act. This research uses a normative research type, with a Legislative approach. As for what is used as primary data, namely Law Number 32 of 2009, Law Number 11 of 2020 concerning Job Creation is the legal basis for knowing criminal arrangements and criminal sanctions against corporate criminal liability for environmental pollution in terms of the work copyright law. Data were collected using library research techniques. After the research data has been collected, it is processed by elaboration, namely combining the sources of the primary, secondary and tertiary legal materials with deductive and inductive logic. The results of this study indicate that corporate crime is essentially a functional act and is in the form of an inclusion offense. The criminal sanction of imprisonment is 1/3 to the management of the corporation.
\end{abstract}

Keywords: Corporate, Environment, Accountability

\section{PENDAHULUAN}

Pada era globalisasi yang melanda negara di seluruh dunia saat ini, keberlangsungan lingkungan hidup sudah mulai mengkhawatirkan dikarenakan banyaknya aktivitas atau kegiatan yang menimbulkan pencemaran lingkungan baik yang dilakukan oleh masyarakat, pemerintah maupun pihak swasta (Urbanus \& Febianti, 2017). Di Indonesia pencemaran lingkungan hidup sudah banyak ditemui beberapa wilayah di Indonesia, akibat dari pencemaran lingkungan hidup tersebut membuat ekosistem baik flora, fauna maupun sumber daya alam lainnya mengalami kerusakan (Suharjo, 2002). Pencemaran terhadap lingkungan hidup tentunya mengakibatkan dampak yang cukup parah terhadap perubahan fisik dari suatu lingkungan misalnya hutan, tanah dan alam sekitarnya.

Saat ini, pencemaran lingkungan hidup merupakan dampak dari adanya kegiatan yang 
dilakukan oleh masyarakat, pemerintah maupun pihak swasta yang tidak memperhatikan kelestarian lingkungan hidup. Padahal salah satu faktor utama yang sangat berpengaruh untuk menjaga kelestarian dan keberlangsungan suatu lingkungan hidup adalah perbuatan dan tingkah laku manusia itu sendiri. Karena manusia memiliki peranan yang sangat vital dalam menjaga dan melestarikan dan menjaga ekosistem yang ada dalam lingkungan hidup agar dapat diwariskan secara turun temurun kepada anak cucu. Tidak dapat dipungkiri bahwa saat ini faktor utama yang berperan dalam rusaknya lingkungan hidup adalah segala aktivitas dan kegiatan usaha yang dijalankan oleh pihak yang berkaitan terhadap lingkungan hidup (Munir Fuady, 2004).

Pelestarian lingkungan hidup diatur dalam Pasal 28H UUD NRI Tahun 1945 yang pada intinya menyatakan bahwa setiap orang atau individu berhak untuk mendapatkan hidup sejahtera dan mendapatkan lingkungan hidup yang baik serta berhak untuk memperoleh suatu layanan kesehatan yang layak dan baik. Seiring perkembangan zaman yang begitu pesat dengan segala tuntutan perubahan yang terjadi dapat dilihat bahwa pencemaran lingkungan hidup dan kerusakan lingkungan hidup seringkali melibatkan pihak korporasi dengan berbagai kegiatan usaha yang dijalankan, pencemaran lingkungan yang dilakukan oleh korporasi meliputi pencemaran terhadap udara, air, tanah maupun pembabatan hutan-hutan yang berada di wilayah negara Indonesia.

Banyak dijumpai kasus pencemaran lingkungan yang akibat dari kegiatan korporasi yang tidak memperhatikan kelestarian lingkungan contohnya kerusakan lingkungan pada sektor tambang, hutan dan sumber daya air, tanah, maupun udara akibat dari kegiatan usaha yang dijalankan oleh korporasi tidak memperhatikan keberlangsungan dan kelestarian suatu lingkungan hidup. Kejahatan korporasi terhadap rusaknya lingkungan hidup yang ada di wilayah negara Indonesia perlu mendapatkan perhatian yang sangat serius dari pemerintah agar tidak memperburuk kerusakan lingkungan hidup yang sudah terjadi (Butarbutar, 2016). Apabila dilihat pengertian dari korporasi, yang dimaksud dengan korporasi adalah suatu badan usaha yang dikelola oleh pemerintah maupun oleh pihak swasta, korporasi yang dikelola oleh pemerintah merupakan korporasi berbentuk perseroan terbatas merupakan badan usaha yang berada di bawah naungan Badan Usaha Milik Negara yang memiliki tugas untuk mengelola segala sumber daya alam maupun sumber daya manusia untuk dimanfaatkan dan dikembangkan dengan tujuan untuk kesejahteraan rakyat, sedangkan korporasi atau badan hukum yang dikelola oleh pihak swasta merupakan badan hukum yang didalamnya terdiri dari para pemegang saham atau yang biasa disebut dengan (RUPS) yang memiliki peranan untuk membantu mengelola dan mengembangkan potensi sumber daya alam maupun sumber daya manusia, selain itu korporasi yang dikelola oleh pihak swasta dapat melakukan kegiatan usaha yang dijalankannya secara mandiri dengan mengajukan izin terhadap pejabat yang berwenang

Kejahatan korporasi yang terjadi di Indonesia sangat banyak dijumpai di berbagai daerah yang ada di Indonesia, tentunya banyak menuai protes dari masyarakat setempat, kejahatan yang dilakukan oleh korporasi meliputi kejahatan terhadap lingkungan, sehingga berdampak terhadap warga sekitar, pengaturan mengenai kejahatan korporasi yang terjadi di Indonesia saat ini belumlah jelas mengenai aturan hukumnya, karena saat ini pengaturan hukum terhadap kejahatan yang dilakukan oleh korporasi terhadap rusaknya lingkungan hidup hanya diatur di dalam Peraturan Mahkamah Agung No. 13 Tahun 2016, tentang tata cara mekanisme dalam menangani kejahatan korporasi dalam melakukan tindak pidana

Ada beberapa penelitian terdahulu yang relevan dengan penelitian ini yaitu dilakukan oleh Santoso, (2016); (Risjani, 2018) mengungkapkan Korporasi masih belum ada aturan pertanggungjawaban secara tegas dalam UU Nomor 39 Tahun 2009 tentang Perlindungan dan Pengelolaan lingkungan Hidup, sehingga masih sulitnya tindak pidana korporasi diterapkan berdasarkan delik lingkungan. Selanjutnya Suharjo, (2002) mengungkapkan bahwa pembuangan sampah yang tidak beraturan akan mengakibatkan efek yang buruk bagi kesehatan masyarakat, untuk mencegah hal ini, sehingga pemerintah membuat peraturan tentang pencemaran lingkungan hidup. Peraturan Mahkamah Agung No. 13 Tahun 2016 belum dirasakan cukup untuk dapat menjerat korporasi yang melakukan tindak pidana dalam bidang kerusakan lingkungan, maka dari itu pemerintah merancang suatu aturan Perundang-undangan dalam bidang investasi, ketenagakerjaan dan pengelolaan sumber daya dalam dalam Rancangan Undang-undang No. 11 Tahun 2020 tentang cipta kerja untuk menangani segala perkara pidana maupun perdata yang dilakukan oleh korporasi dalam bidang investasi, ketenagakerjaan dan pengelolaan sumber daya alam.

Berdasarkan penjabaran fenomena yang telah dipaparkan oleh peneliti terdahulu, maka 
penelitian ini dilakuakn dengan tujuan mengkaji pengaturan tindak pidana oleh korporasi dalam perspektif undang-undang cipta kerja dan mengungkapkan sanksi pidana terhadap korporasi yang melakukan tindak pencemaran lingkungan ditinjau dari undang-undang cipta kerja

Sehingga tujuan daripada dilakukannya penelitian ini adalah:

\section{METODE PENELITIAN}

Penelitian ini menggunakan tipe penelitian normatif yaitu penelitian yang menggunakan pengkajian masalah melalui pendekatan peraturan Perundang-undangan yang berlaku atau hukum positif di Indonesia, sehingga pengkajian masalah melalui pendekatan undang-undang menjadi sumber bahan hukum utama (Hartono, 1994). Selanjutnya sumber bahan hukum sekunder yang digunakan dalam adalah menggunakan pendekatan pengkajian melalui buku-buku akademik sebagai penunjang dalam memecahkan masalah-masalah yang dihadapi, sedangkan sumber bahan hukum tersier yang digunakan dalam pemecahan masalah adalah dengan menggunakan kamus-kamus hukum, jurnal yang memiliki kaitan erat dengan permasalahan yang diteliti mengkaji dan memecahkan suatu permasalah yang dihadapi ketika melakukan penelitian ini. Teknik pengumpulan sumber bahan hukum yang digunakan dalam penelitian ini adalah dengan menggunakan teknik studi pustaka guna membantu memecahkan masalah-masalah yang diteliti ketika melakukan penelitian, langkah-langkah yang dilakukan ketika mengumpulkan sumber bahan hukum dalam penelitian ini yakni terlebih dahulu mencari sumber bahan hukum primer meliputi peraturan perundang-undangan, kamus penunjang, selanjutnya melakukan filterisasi dalam memilah-milah sumber bahan hukum yang sudah terkumpul tadi, apabila sudah terkumpul maka digunakan teknik elaborasi yakni menggabungkan sumber bahan hukum primer, sekunder dan tersier tadi dengan logika deduktif dan induktif dari penulis (Bambang Sunggono, 2011).

\section{HASIL DAN PEMBAHASAN}

\section{Pengaturan Tindak Pidana Korporasi dalam Undang-undang Cipta Kerja}

Kelestarian lingkungan hidup di Indonesia diatur pada dasar negara Indonesia yang pada intinya menyatakan bahwa setiap orang atau setiap individu berhak untuk kehidupan yang layak. Seiring perkembangan zaman yang begitu pesat dengan segala tuntutan perubahan yang terjadi dapat dilihat bahwa pencemaran lingkungan hidup dan kerusakan lingkungan hidup seringkali melibatkan pihak korporasi dengan berbagai kegiatan usaha yang dijalankan, pencemaran lingkungan yang dilakukan oleh korporasi meliputi pencemaran terhadap udara, air, tanah maupun pembabatan hutan-hutan yang berada di wilayah negara Indonesia. Banyak dijumpai kasus-kasus pencemaran lingkungan hidup yang dilakukan oleh korporasi yang terjadi di Indonesia, contohnya kerusakan lingkungan pada sektor tambang, hutan dan sumber daya air, tanah, maupun udara akibat dari kegiatan usaha yang dijalankan oleh korporasi tidak memperhatikan keberlangsungan dan kelestarian suatu lingkungan hidup. Kejahatan korporasi terhadap rusaknya lingkungan hidup yang ada di wilayah negara Indonesia perlu mendapatkan perhatian yang sangat serius dari pemerintah agar tidak memperburuk kerusakan lingkungan hidup yang sudah terjadi.

Untuk mengisi dan menjawab kekosongan hukum yang ada terhadap kejahatan korporasi, saat ini pemerintah melalui Mahkamah Agung telah merumuskan Perma No. 13 Tahun 2016 sebagai acuan dalam menangani kejahatan korporasi dari korporasi agar dalam segala kegiatan usaha yang dijalankan agar selalu memperhatikan kelestarian dan keberlangsungan lingkungan hidup, Namun perlu diketahui bahwa Perma No. 13 Tahun 2016 dirasa belum cukup untuk menjerat korporasi yang melakukan suatu tindak pidana, diperlukan suatu peraturan perundang-undangan yang memang dapat menjadi suatu pedoman untuk melakukan penegakan hukum terhadap segala tindak pidana yang dilakukan oleh korporasi

Saat ini pemerintah telah berupaya untuk segera melakukan pengesahan terhadap RUU Nomor 11 Tahun 2020 tentang Cipta Kerja atau yang biasa disebut dengan Rancangan Undangundang Cipta Kerja. Di dalam Rancangan Undang-undang Cipta Kerja tidak mengatur secara langsung mengenai apa yang dimaksud tindak pidana yang dilakukan oleh korporasi, tetapi hanya menjelaskan apa yang dimaksud dengan korporasi yang diatur di dalam pasal 1 angka 15 . Pengaturan sanksi pidana terhadap korporasi yang melakukan suatu tindak pidana telah diatur pasal 74 yang menyatakan bahwa: (1) Dalam hal tindak pidana sebagaimana dimaksud dalam Pasal 69, Pasal 70, atau 71 dilakukan oleh suatu korporasi, selain pidana penjara dan denda terhadap pengurusnya dapat 
dikenai pemberatan hukuman sebanyak $1 / 3$ kali dan dikenakan pidana denda sebagaimana diatur pada Rancangan Undang-Undang No. 11 Tahun 2020 Tentang Cipta Kerja (Gani, 2011)

\section{Sanksi Pidana Terhadap Korporasi yang Melakukan Pencemaran Lingkungan Ditinjau dari Undang-undang Cipta Kerja}

Di Indonesia sudah banyak dijumpai kasus-kasus pencemaran lingkungan hidup yang dilakukan oleh korporasi, contohnya kerusakan lingkungan pada sektor tambang, hutan dan sumber daya air, tanah, maupun udara akibat dari kegiatan usaha yang dijalankan oleh korporasi tidak memperhatikan keberlangsungan dan kelestarian suatu lingkungan hidup. Kejahatan korporasi terhadap rusaknya lingkungan hidup yang ada di wilayah negara Indonesia perlu mendapatkan perhatian yang sangat serius dari pemerintah agar tidak memperburuk kerusakan lingkungan hidup yang sudah terjadi. Membahas mengenai sanksi pidana, yang dimaksud dengan sanksi pidana adalah, suatu konsep yang mendasar mengenai pengenaan sanksi pidana yaitu apabila terdapat kesalahan, maka dari itu yang dimaksud dengan sanksi pidana adalah, seseorang dapat dikenakan sanksi pidana apabila seseorang telah melanggar ketentuan yang terdapat dalam peraturan perundang-undangan, atau seseorang dapat disalahkan karena telah melanggar ketentuan yang terdapat dalam peraturan perundangan-undangan sehingga dapat dikenakan sanksi secara pidana (Hamzah, 1983).

Membahas mengenai pertanggungjawaban pidana terhadap korporasi yang melakukan tindak pidana pencemaran lingkungan, dalam hal ini korporasi merupakan badan hukum yang struktur kepengurusannya terdiri dari direksi sebagai pengawas kegiatan usaha yang dilakukan oleh direktur suatu korporasi dalam hal ini yang bertanggungjawab dalam mengawasi dan melaksanakan segala kegiatan usaha yang dilakukan oleh korporasi adalah direksi dan direktur dari korporasi tersebut, sehingga dewan direksi dan direktur dapat dikenakan pertanggungjawaban pidana atas kegiatan usaha yang dijalankan oleh korporasi tersebut, selain pertanggungjawaban secara pidana, korporasi tersebut dapat dikenakan pertanggungjawaban secara perdata mulai dari diberikannya sanksi administratif, pembekuan kegiatan usaha hingga pencabutan izin usaha yang dimiliki oleh korporasi tersebut yang diterbitkan oleh pejabat yang berwenang.

Sanksi pertanggungjawaban pidana terhadap korporasi yang melakukan tindak pidana pencemaran lingkungan di Indonesia saat ini belum memiliki pengaturan yang jelas mengenai dasar hukum untuk dapat menjerat korporasi yang melakukan tindak pidana pencemaran lingkungan tersebut, saat ini di Indonesia hanya memiliki Peraturan Mahkamah Agung No.13 Tahun 2016 tentang mekanisme dalam menangani tindak pidana yang dilakukan oleh korporasi, saat ini peraturan mahkamah agung tersebut belum dirasakan secara efektif dalam menangani berbagai kasus pencemaran lingkungan yang dilakukan oleh korporasi sehingga pemerintah menerbitkan Rancangan peraturan perundang-undangan No. 11 Tahun 2020 tentang Cipa Kerja, dimana peraturan ini dibentuk untuk menangani segala perkara investasi, ketenagakerjaan dan pengelolaan sumber daya alam yang dilakukan oleh korporasi, sehingga sanksi pertanggungjawaban pidana terhadap korporasi yang melakukan tindak pidana pencemaran lingkungan dapat dijerat dengan pasal 74 yang menyatakan bahwa: (1) Dalam hal tindak pidana sebagaimana dimaksud dalam Pasal 69, Pasal 70, atau 71 dilakukan oleh suatu korporasi, selain pidana penjara dan denda terhadap pengurusnya, pidana denda dengan pemberatan 1/3 (sepertiga) kali dari pidana denda sebagaimana dimaksud dalam pasal 69, pasal 70, atau pasal 71 Rancangan Undang-undang No. 11 Tahun 2020 tentang Cipta Kerja.

\section{SIMPULAN DAN SARAN}

\section{Simpulan}

Berdasarkan analisis data, diketahui bahwa di Indonesia Undang-undang Nomor 11 Tahun 2020 tentang Cipta Kerja tidak mengatur secara langsung apa yang dimaksud dengan tindak pidana oleh korporasi, tetapi dalam Pasal 1 Angka 15 menyatakan bahwa Korporasi adalah kumpulan orang dan/atau kekayaan yang terorganisasi, baik merupakan badan hukum maupun bukan badan hukum". pengaturan pertanggungjawaban pidana terhadap korporasi yang melakukan tindak pidana pencemaran lingkungan dapat dijerat dengan pasal 74, Pasal 69, pasal 70, atau pasal 71 Rancangan Undang-undang No. 11 Tahun 2020 Tentang Cipta Kerja. Sanksi pertanggungjawaban pidana terhadap korporasi yang melakukan tindak pidana kejahatan lingkungan, dalam hal ini yang bertanggungjawab dalam mengawasi dan melaksanakan segala kegiatan usaha yang dilakukan oleh 
korporasi adalah direksi dan direktur dari korporasi tersebut, sehingga dewan direksi dan direktur dapat dikenakan pertanggungjawaban pidana atas kegiatan usaha yang dijalankan oleh korporasi tersebut.

\section{Saran}

Berkaitan simpulan penelitian, adapun saran yang diberikan yaitu pemerintah hendaknya melakukan penegakan hukum terhadap tindak pidana pencemaran lingkungan yang dilakukan oleh korporasi, di dalam UU No. 11 Tahun 2020 tentang Cipta Kerja, dan memuat aturan mengenai pertanggungjawaban terhadap pemulihan lingkungan hidup yang telah dirusak oleh korporasi tersebut, mengingat sanksi pertanggungjawaban pidana yang diatur di dalam UU No. 11 Tahun 2020 tentang Cipta Kerja masih tergolong ringan dibandingkan efek kerusakan lingkungan yang ditimbulkan yang dapat mengganggu masyarakat sekitar yang terkena dampak dari kerusakan lingkungan. Diharapkan para penegak hukum lebih tegas lagi dalam menangani kejahatan pencemaran lingkungan yang dilakukan oleh korporasi, meningkat kejahatan pencemaran lingkungan sangatlah berbahaya karena dapat mengancam keberlangsungan lingkungan hidup serta ekosistem yang terdapat didalamnya.

\section{DAFTAR PUSTAKA}

Bambang Sunggono. (2011). Metedologi Penelitian Huku

Butarbutar, R. (2016). Pertanggungjawaban Pidana Partai Politik dalam Tindak Pidana Korupsi dan Pencucian Uang. Jurnal Ilmu Hukum (Journal of Law), 3(2), 351-371.

Gani, R. bdul. (2011). Kejahatan Korporasi yang Ditinjau dari Pertanggungjawaban Pidana.

Hamzah, A. (1983). Pengantar Hukum Acara Pidana. Jakart. Ghalia Indonesia.

Hartono, S. (1994). Penelitian Hukum di Indonesia pada Akhir Abad ke-20. Bandung: Alumni Bandung.

Munir Fuady. (2004). Pencemaran Lingkungan Ditinjau Dari Aspek Yuridis. Prenada Media: Jakarta.

Risjani, O. jufri dan Y. (2018). Indikator Pencemaran Lingkungan. Yogyakarta: Deepublish.

Santoso, M. A. (2016). Pertanggungjawaban Pidana Pencemaran Lingkungan Hidup yang Dilakukan oleh Korporasi. Jurnal Cakrawala Hukum, 7(2), 216-228.

Suharjo. (2002). Kondisi Pengelolaan Sampah dan Pengaruh Terhadap Kesehatan Masyarakat di Dki Jakarta. In Media Litbang Kesehatan (Vol. 12, Issue 4, pp. 37-42).

Urbanus, N., \& Febianti. (2017). Analisis Dampak Perkembangan Pariwisata terhadap Perilaku Konsumtif Masyarakat Wilayah Bali Selatan. Jurnal Kepariwisataan Dan Hospitalitas, 1(No.2), $118-133$. 